\title{
HAPPINESS LEVELS STABILITY
}

\author{
Ruut Veenhoven
}

In: Alex C. Michalos (Ed.) Encyclopedia of Quality of Life and Well-Being Research Springer, Dordrecht, Netherlands, 2014. Springer Reference Series, pp. 1262-1265. ISBN 978-94-007-0752-8

DOI:10.1007/978-94-007-0753-5_2844

\section{DEFINITION}

The degree to which happiness tends to remain at the same level over time.

\section{SYNONYMS}

Happiness set point; Trait likeness of happiness

\section{DESCRIPTION}

\subsection{Presumed Stability of Happiness}

One of the ideological foundations of the modern welfare states is the belief that people can be made happier by providing them with better living conditions. This belief is challenged by the idea that happiness tends to remain at the same level and will therefore hardly change when living conditions improve. This counter intuitive thought draws to two theories of happiness.

One theory holds that happiness is a fixed "trait," rather than a variable "state." This theory figures both at the individual level and at the societal level. The individual level variant depicts happiness as an aspect of personal character, rooted in inborn temperament or acquired disposition and is commonly referred to as the "set point" theory of happiness. The societal variant sees happiness as a matter of national character, embedded in shared values and beliefs. This variant has been called "folklore theory." Both variants imply that a better society makes no happier people.

The second theory holds that happiness is a matter of comparison and that different standards of comparison are involved, such as described in Michalos (1985) " multiple discrepancies theory" of happiness. In that context it is then assumed that standards tend to shift over time and that these shifts nullify the effects of improvements in living conditions. This is seen to lead us in a "hedonic treadmill," where we remain equally happy subjectively in spite of progress in an objective sense (e.g., Brickman \& Campbell, 1971).

This idea of stable happiness figures in several discussions, one of which is the debate on the value of economic growth. In that context the "Easterlin Paradox" 
holds that average happiness in nations has remained at the same level over the last decade in spite of constant economic growth (Easterlin, 1974).

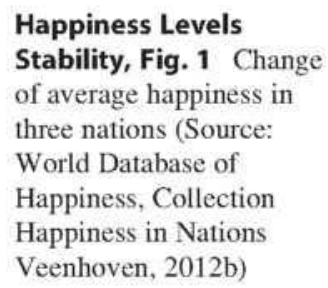

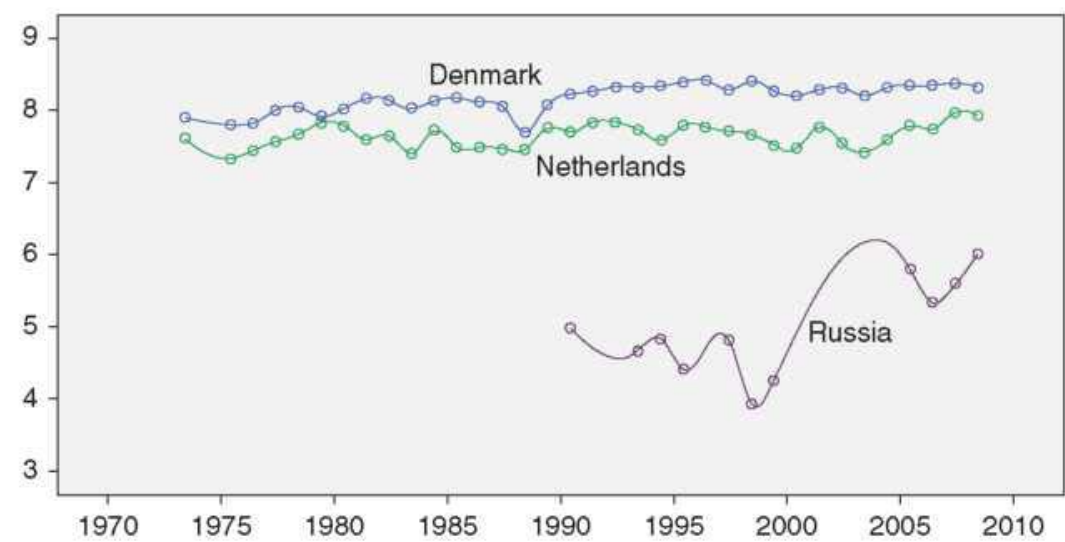

\subsection{Observed Changes of Happiness}

The variability of happiness over time has been investigated at two levels, at the micro level of individuals and at the macro-level of nations. An overview of the research literature is available in the Bibliography of the World Database of Happiness (Veenhoven, 2012a), in section "Prevalence of Happiness" (code D), respectively, in the subsections "How Stable Is Happiness" (code Dc) and "Trend in National Happiness" (Code De01.01).

\section{Change of Individual Happiness}

Follow-up studies show that happiness is typically quite stable on the short term, but not in the long run, neither relatively nor absolutely. The year-to-year correlation between self-reports of happiness is about 0.50 , but over a period of 10 years, the correlation drops to less than 0.30 (e.g., Ehrhardt, Saris, \& Veenhoven, 2000).

Happiness does change in reaction to life events, such as marriage, bereavement, illness, and unemployment. Some of these effects are short lived, such as in the case of financial windfalls (Gardner \& Oswald, 2001), while others are lasting, such as typically in the case of unemployment (e.g., Clark, Diener, Georgellis, \& Lucas, 2008). Another typical change of this kind is the decline of happiness in the year before death (Gerstorf \& Wagner, 2010).

\section{Change of Average Happiness in Nations}

Trend studies on average happiness in nations show more stability, the earliest studies in particular. Happiness has remained at about the same level in the USA between its first assessment in 1948 and the most recent in 2010. Likewise, average happiness changed little in Japan since the first survey in 1958. These first findings were taken as a general pattern, among other by Easterlin. Yet later time series in more countries over longer periods showed that happiness has risen in most countries. A recent analysis of 197 time series in 66 nations revealed a change to the better in two-third of these cases (Veenhoven \& Vergunst, 2013).

Some examples of long-term change of average happiness in nations are presented in Fig. 1. In Denmark, average happiness raised half a point on scale 0-10 over this period, while in the Netherlands, average happiness has fluctuated around the same level of 7.5 until the year 2000 but has increased since. The Russian data show ups and downs and as such most clearly contradict the idea of immutable happiness. 
Some of these changes in average happiness in nations are clearly linked to particular events. The dip in happiness in Russia in the late 1990s coincided with the "Ruble crisis," and the decline of happiness since 2008 in Greece, Spain, and Portugal is also a reaction to the economic recession. The effects of economic growth are less well visible. Still the above-mentioned analysis of Veenhoven and Vergunst revealed a correlation of 0.20 between economic growth and change of happiness in nations.

A complete overview of time trends is available in the collection "Happiness in Nations" of the World Database of Happiness (Veenhoven, 2012b). A selection of time series of at least 5 data point in 20 years is available on the trend report of average happiness in nations (Veenhoven, 2012c), which is periodically updated.

\subsection{Theoretical Implications}

These findings do not support the abovementioned theories of happiness, happiness is clearly not a fixed trait, and reference shifts do not nullify the effects of all progress. The findings fit better with the livability theory of happiness, discussed elsewhere in this encyclopedia. 


\section{REFERENCES}

Brickman, P., \& Campbell, D. T. (1971)

Hedonic relativism and planning the good society.

In M. H. Appley (Ed.), Adaptation level theory (pp. 287-302).

New York: Academic.

Clark, A. E., Diener, E., Georgellis, Y., \& Lucas, R. E. (2008)

Lags and leads in life satisfaction: A test of the baseline hypothesis.

The Economic Journal, 118, 222-243.

Easterlin, R. A. (1974)

Does economic growth improve the human lot?

In P. A. David \& W. R. Melvin (Eds.), Nations and households in economic growth (pp. 89-125).

New York: Academic.

Ehrhardt, J., Saris, W., \& Veenhoven, R. (2000)

Stability of life-satisfaction over time. Analysis of change in ranks in a national population.

Journal of Happiness Studies, 1, 177-205.

Gardner, J., \& Oswald, A. J. (2001)

Does money buy happiness? A longitudinal study using data on windfalls.

Warwick, UK: Paper University of Warwick.

Gerstorf, D., \& Wagner, G. G. (2010)

Lebenszufriedenheit am Ende des Lebens in Ost-und Westdeutschland: Die DDR

wirft noch einen langen Schatten. (Life satisfaction at the end of life in East and

West Germany). In P. Krause \& I. Ostner (Eds.), Leben in Ost-und

Westdeutschland (pp. 429-439).

Frankfurt, Germany: Campus Verlag.

Michalos, A. C. (1985)

Multiple discrepancies.

Theory Social Indicators Research, 16, 347-413.

Veenhoven, R. (2012a)

World Database of Happiness: Archive of research findings on subjective enjoyment of life.

Netherlands: Erasmus University Rotterdam.

http://worlddatabaseofhappiness.eur.nl 
Veenhoven, R. (2012b).

Bibliography of happiness.

Rotterdam: World Database of Happiness, Erasmus University.

http://worlddatabaseofhappiness.eur.nl/habib/bib_fp.php

Veenhoven, R. (2012c).

Happiness in nations.

Rotterdam: World Database of Happiness, Erasmus University.

http://worlddatabaseofhappiness.eur.nl/hap_nat/nat_fp.php

Veenhoven, R., \& Vergunst, F. (2014)

The Easterlin Illusion

International Journal of Happiness and Development 2 (in press)

These findings do not support the abovementioned theories of happiness, happiness is clearly not a fixed trait, and reference shifts do not nullify the effects of all progress. The findings fit better with the livability theory of happiness, discussed elsewhere in this encyclopedia.

\title{
Cross-References in encyclopedia:
}

\author{
Easterlin Paradox \\ Happiness \\ Happiness Measures \\ Need Theory \\ Set Point Theory \\ World Database of Happiness
}

